\title{
Using Polypropylene for Bronchial Stump Closure After Pulmonary Resections
}

\author{
BOGDAN ANDREI SUCIU1,2, IOANA HALMACIU1*, VASILE BUD², CONSTANTIN COPOTOIU2, \\ DECEBAL ROMULUS PETRU FODOR ${ }^{1,2}$, CRISTIAN TRAMBITAS ${ }^{1}$, VLAD VUNVULEA ${ }^{1}$, CALIN MOLNAR ${ }^{2}$, KLARA BRINZANIUC ${ }^{1}$ \\ ${ }^{1}$ University of Medicine and Pharmacy, Department of Anatomy, 38 Gheorghe Marinescu Str., 540142, Tirgu Mures, Romania \\ 2 University County Hospital, $1^{\text {st }}$ Surgical Clinic, 50 Gheorghe Marinescu Str., 540136, Tirgu Mures, Romania
}

The bronchial stump fistula shown by patients undergoing adjusted pulmonary resections is an extremely severe condition affecting the prognosis of this patients. Within our study, we have used an innovative technique of closing the bronchial stump for 38 patients undergoing adjusted pulmonary resections. The suture of the bronchial stump was made through an innovative method, by practicing the suture with isolated 2.0 Prolene wires armed with patches of Polypropylene. The incidence of the bronchial stump fistula for the observed lot was of 5.26\% (2 cases), smaller than the one reported in the specialty literature. In this respect, we consider that the use of Polypropylene in the techniques of closing the bronchial blunt can be beneficial.

Keywords: polypropylene, bronchial stump fistula

Adjusted pulmonary resections performed on patients with non-small cell lung cancer represent surgical interventions with high morbidity and mortality. One of the main complications which these patients can present is the bronchial stump fistula. The incidence of these fistulas can vary between 0 and $20 \%$ according to the experience of the surgical team and according to the type of the surgical intervention [1]. Certain authors have observed that covering the bronchial stump following its closure can decrease the incidence of the bronchial fistulas in these cases. Usually, for these cases tissues close to the bronchial stump are preferred, such as: the nearest parietal pleura, the peduncle of intercostal muscle, a fragment from the pericardium or fat tissue [2].

The purpose of this present study is to evaluate the impact of an innovative surgical technique of closing the bronchial stump following pulmonary resections by using non-resorbable suture wires armed with patches of Polypropylene.

\section{Experimental part}

For the purpose of this present study we have performed a retrospective clinical observational study for which we have integrated a number of 38 patients with the diagnosis of non-small cell lung cancer upon whom adjusted pulmonary resections were performed (Lobectomy, Bilobectomy, Pneumonectomy). The patients were hospitalized and underwent surgery at the no. 1 Surgery Clinic within the Mure' County Clinical Emergency Hospital. The necessary data for the study were obtained by analysing the observation sheets of the patients and the surgical registry books. The statistical analysis of the data was performed by using the Microsoft Excel soft.

As a criteria of selecting the patients for the performance of the study, we have used only patients with non-small cell lung cancer upon whom adjusted pulmonary resections were performed. For the studied patients, an innovative technique of closing the bronchial stump was used. Following the period of pulmonary surgical removal, the closing of the bronchial stump was performed by suturing the bronchial stump with isolated wires of 2.0 Prolene armed with patches of Polypropylene, which practically achieved the retaining from the exterior of the bronchial stump (fig. 1-3).
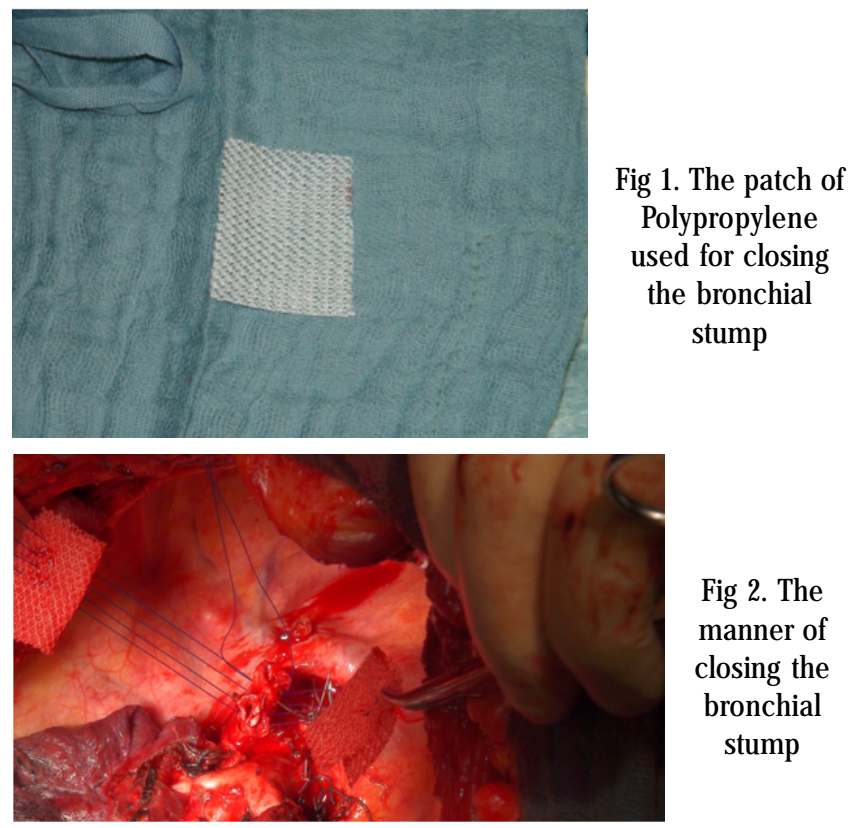

Fig 2. The manner of closing the bronchial stump

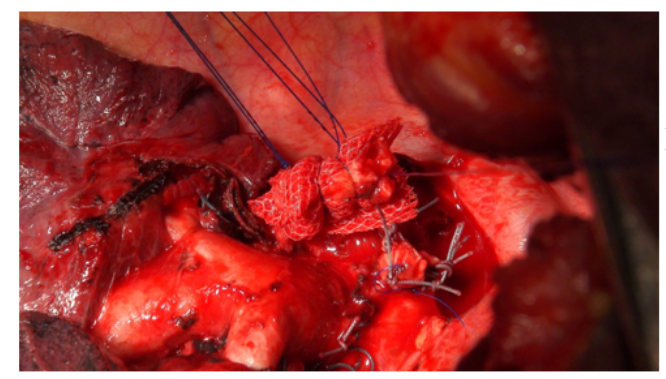

Fig 3. The final aspect of the bronchial stump

For all the studied patients we have tried to study the existence of some eventual comorbidities which can represent risk factors for the appearance of the postoperative bronchial stump fistula, such as: diabetes mellitus, pre-existent cardiac diseases, perioperative transfusions, right pneumonectomy. 


\section{Results and discussions}

Within this study we have introduced a number of 38 patients suffering from non-small cell lung cancer who underwent adjusted pulmonary resections. The studied patients were distributed in 3 lots according to the performed surgical intervention: lobectomy, bilobectomy and pneumonectomy. Regarding the distribution of patients in the 3 lots, we have obtained the following results: 29 patients underwent pulmonary lobectomy $(76.31 \%$ of the cases), 5 patients underwent a pulmonary bilobectomy (13.15\% of the cases) and 5 patients underwent a left pneumonectomy ( $10.52 \%$ of the cases) (fig. 4). We did not register within the studied lot patients upon whom right pneumonectomy was performed.

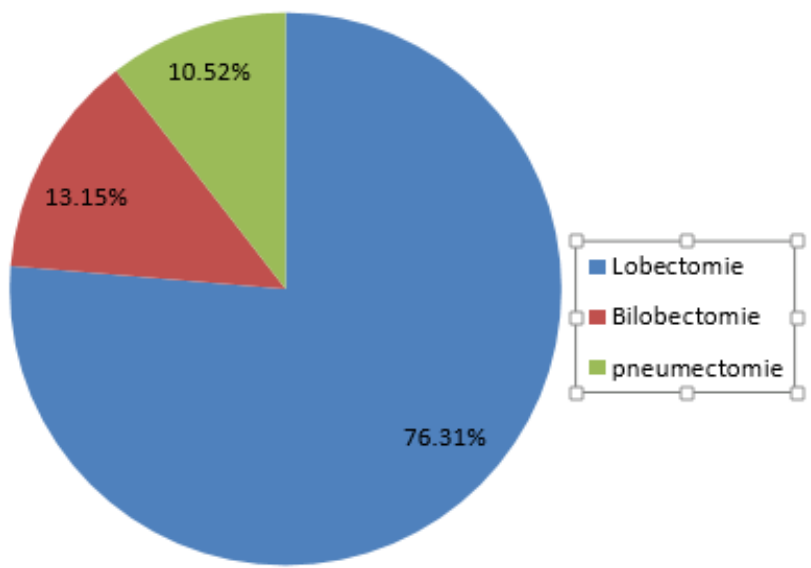

Fig 4. The types of performed surgical interventions

The clinical-pathological characteristics of the patients involved in the study are show in table 1.

From the analysis of the studied lot, we did not register any patients upon whom right pneumonectomy was performed. This was possible due to an adequate selection of the patients who underwent a pneumonectomy, especially on the right side. It is a known fact that right pneumonectomy is a surgical intervention with a very increased morbidity as following this intervention, an extremely large ventilation surface is removed, which in some cases can prove to be fatal for the patient.

In what regards the incidence of the bronchial stump fistula, we have registered a number of 2 cases $(5.26 \%$ of the cases), for a case of lobectomy and one of bilobectomy. We have to mention the fact that the patient upon whom a
Lobectomy was performed was also suffering from diabetes mellitus (a risk factor for the appearance of the postoperative bronchial stump fistula) and both patients presented chronic ischemic cardiopathy. None of the two patients received a perioperative transfusion. If we compare our data to those from the specialty literature, we can conclude that they fit to those published by the big surgical centres in the world. Basically, the principle of retaining from the exterior for the bronchial stump closure techniques was used also by other authors [2,3].

Moreover, within the lotstudied by us, we have registered a death (mortality of $2.63 \%$ ), and the cause of the death was not caused by bronchial fistula, but by a respiratory failure which could notbe compensated by treatment with drugs.

Polypropylene is a thermic plastic polymer with multiple used in the industry of plastic masses, and in the last decades it is more and more used in medicine, especially in surgery. In medicine, as a plastic material, it is used for the production of syringes or containers, or also in the shape of meshes. The polypropylene mesh is used in multiple surgical reconstruction techniques, but so far it was not used in thoracic surgery for the techniques of closing the bronchial stump. Initially, it was used for the surgery of inguinal hernias and incisional hernias [4]. The polypropylene belts are currently used for the surgical treatment of genital prolapse [5].

For this purpose, itwas proved the fact that polypropylene integrates very well in human tissues, producing reduced reactions of rejection or of inflammations due to foreign body. [6,7] Certain studies proved the fact that, after introducing the polypropylene prosthesis within the human organism, on the abdominal wall, at the level of the place of implantation an initial local inflammation with a reduced fibroblastic reaction is produced, and in time a resistant scar is produced [8]. It was also demonstrated the fact that, compared to other heterologous materials placed at the level of the human tissue, the inflammatory reaction induced by polypropylene is considerably reduced $[9,10]$.

It is currently a known fact that the tissue integration of polypropylene prosthesis depends greatly upon the dimension of the pits from the mesh's structure. The tissue integration of the polypropylene mesh is greater proportionally to the small dimensions of these pits [11]. Within our study, we have used polypropylene patches which presented pits with a diameter of 1-2 $\mathrm{mm}$. this fact

\begin{tabular}{|l|c|c|c|}
\hline Studied parameter & Lobectomie & Bilobectomie & Pneumectomie \\
\hline Age & $43-75$ & $55-70$ & $56-69$ \\
\hline Sex (M /F) & $22 / 7$ & $3 / 2$ & $3 / 1$ \\
\hline Diabetes mellitus & 2 & 1 & 0 \\
\hline Perioperative transfusions & 4 & 1 & 1 \\
\hline Preexistent cardiac diseases & 7 & 4 & 3 \\
\hline Pneumectomye dr & ---1 & 1 \\
\hline Biochemical stump fistula & 1 & 1 & 0 \\
\hline Death & & 0 & 0 \\
\hline Total pacients & 1 & 5 & 4 \\
\hline
\end{tabular}

Table 1

THE CLINICAL-PATHOLOGICAL CHARACTERISTICS OF THE PATIENTS INVOLVED IN THE STUDY 
probably explains the good results obtained by us within this study. Other authors have proved that the greater the dimension of the polypropylene prosthesis, the bigger will be the reaction of local inflammation.[12]. During the study performed by us, we have used patches of polypropylene of small dimensions (3-4 cm diameter).

The surgical techniques of closing the bronchial stump currently remain a controversial subject of thoracic surgery. There are multiple techniques of closing the bronchial stump accepted by the specialty literature. Classically, there are 2 categories of techniques of closing the bronchial stump: the manual suture and the mechanic suture. The mechanic suture has the advantage of being practiced with the closed bronchial blunt, which prevents the contamination of the surgical field $[13,14]$. Although safer, the mechanic suture has the disadvantage of being more expensive. In the case of performing a manual suture of the bronchial stump, there are multiple technical variants of performing it, as there is no current unanimous consensus within the specialty literature [15-17].

There are also controversies regarding the coating of the bronchial stump with surrounding tissues. While some authors consider that this procedure is beneficial for preventing the bronchial stump fistula, others consider that the results of this procedure are contradictory. However, based on our experience, we consider that the retaining from the exterior of the bronchial blunt is beneficial [1820].

\section{Conclusions}

Within the study performed by us, we have used an innovative method of closing the bronchial stump. Using polypropylene in the techniques of closing the bronchial stump following pulmonary resections can be beneficial. It is further on required the performance of random studies on a greater number of patients for the purpose of introduction this technique within the current clinical practice.

\section{References}

1.CERFOLIO RJ., Semin. Thorac. Cardiovasc. Surg., 13, nr.1, 2001, p.3-7

2.KLEPETKO, W., TAGHAVI S., PERESZLENYI A., BIRSAN T., GROETZNER J., KUPILIK N., ARTEMIOU O., WOLNER E., Eur. J. Cardiothorac. Surg., 15,1999,nr.6, p.758-763

3.MATSUOKA K., IMANISHI N., YAMADA T., MATSUOKA T., NAGAI S., UEDA M., MIYAMOTO Y., Interact. Cardiovasc. Thorac. Surg., 23,2016,nr.4, p.553-559

4. POTECA, T.D., MIHAILA, D.E., IONESCU, S.O., POTECA, A.G., TAMPA, M., MATEl, C., Mat. Palst., 50, no. 2, 2013, p. 134

5.PRZYDACZ M, ADLI O., MAHFOUZ W., LOUTOCHIN O., BEGIN LR., CORCOS J., Cent. European. J. Urol., 70,2017, nr. 2, p.154-62

6.ZHANG K., HAN J., YAO Y., YANG J., QIAO J., Int. Urogynecol. J., 23,2012, nr. 5, p.605-611

7.KAVVADIAS T., KAEMMER D., KLINGE U., KUSCHEL S., SCHUESSLER B., J. Pelvic. Dysfunct., 20, 2009, p.1473-1476

8.DONATI M., BRANCATO G., GROSSO G., LI VOLTI G., LA CAMERA G., CARDI F., BASILE F., DONATI A., Medicine, 95, 2016, nr.24, .p e3791 9.KELLY M., MACDOUGALL K., OBLAISI D., MCGUIRE N., Int. Urogynecol. J., 28,2017, p.171-180

10. BRATU, D., BOICEAN, A., TANASESCU, C., SOFARIU, C., MIHETIU, A., CERNUSCA MITARIU, I.S., OGNEAN, L., MOLDOVAN, C., BOITOR, C., Mat. Plast., 54, no. 1, 2017, p. 119

11.CONZE J ., ROSCH R., KLINGE U., WEISS C., ANUROV M., TITKOWA S., OETTINGER V., SCHUMPELICK V., Hernia, 8, 2004, nr.4, p.365-372 12.DI VITA G., D'AGOSTINO P., PATTIR., ARCARA M., CARUSO G., DAVI V., CILLARI E., Langenbecks Arch. Surg., 390,2005, nr.4, p.306-311 13.ALKATTAN K., CATTELANI L., GOLDSTRAW P., Eur. J . Cardiothorac. Surg., 9,1995, p.479-482

14.FORRESTER CP., J. Thorac. Cardiovasc. Surg., 80,1980,p.406-409 15.SWEET RH., Surgery, 18,1945, p.82-84

16.VERRAIN C, CAYOT M., VIARD H., Ann. Chir., 33,1979, p.147-150

17.HUBAUT J] ., BARON O., AL HABASH O., DESPINS P., DUVEAU D., MICHAUD JL., Eur. J. Cardiothorac. Surg, 16,1999,NR.4, p.418-423

18.BUD V., SUCIU BA., BUTIURCA V., BRINZANIUC K., COPOTOIU R., COPOTOIU C., SIN A., Rom. J. Morphol. Embryol., 54,2013,nr.1,p.115119

19.ASAMURA H., NARUKE T., TSUCHIYA R., J. Thorac. Cardiovasc. Surg., 104,1992, p.1456-1464

20.WRIGHT CD., WAIN J C., MATHISEN DJ ., J . Thorac. Cardiovasc. Surg., 98,1989,p.1367-1371

Manuscript received: 4.03.2017 